\title{
Spectral bimodality of waves produced by hurricanes in the Caribbean coastal zone off Mexico
}

\section{Bimodalidad espectral del oleaje provocado por huracanes en la zona costera del caribe mexicano}

\author{
Raúl Martell-Dubois ${ }^{1}$, Rodolfo Silva-Casarin², Edgar G Mendoza-Baldwin², Juan J Muñoz-Pérez ${ }^{3}$, \\ Sergio Cerdeira-Estrada ${ }^{1}$, Edgar Escalante-Mancera ${ }^{4}$, Irene Laiz ${ }^{3}$ \\ ${ }^{1}$ Comisión Nacional para el Conocimiento y Uso de la Biodiversidad (CONABIO), Liga Periférico- \\ Insurgentes Sur 4903, Parques del Pedregal, CP 14010, Tlalpan, Mexico City. \\ 2 Instituto de Ingeniería, Universidad Nacional Autónoma de México (UNAM), Av. Universidad 3000, \\ Cd. Universitaria, CP 04510, Coyoacán, Mexico City. \\ ${ }^{3}$ Centro Andaluz Superior de Estudios Marinos, Universidad de Cádiz, Av. República Árabe Saharawi, s/n, \\ 11510 Puerto Real, Cádiz, Spain. \\ ${ }^{4}$ Unidad Académica de Sistemas Arrecifales, Instituto de Ciencias del Mar y Limnología, Universidad \\ Nacional Autónoma de México (UNAM), Prol. Av. Niños Héroes s/n, CP 77580, Puerto Morelos, Quintana \\ Roo, Mexico. \\ * Corresponding author. E-mail: rmartell@conabio.gob.mx
}

\begin{abstract}
Wave data collected near the Caribbean coast of Mexico were used to study the frequency and directional structure of the wave field that was generated during the passing of 3 hurricanes. The data were recorded with 2 different acoustic wave gauges, which were installed at a depth of about $20 \mathrm{~m}$. These records provided 183 directional wave spectra corresponding to the occurrence of hurricanes Wilma (October 2005), Dean (August 2007), and Rina (October 2011). The simultaneity of wind waves and swell was detected from different directions, due to the presence of bimodal spectra. For the 3 events, the relation between the translational speed of hurricanes and wave group celerity can explain the presence or absence of spectral bimodality, in either frequency or direction.
\end{abstract}

Key words: wave, spectral bimodality, hurricane, Caribbean.

RESUMEN. Datos de oleaje recolectados próximos a la costa caribeña de México se utilizaron para estudiar la frecuencia y la estructura direccional del campo de oleaje que se generó como consecuencia del paso de 3 huracanes. Los datos se registraron con 2 equipos acústicos diferentes que miden oleaje, los cuales fueron instalados a una profundidad cercana a los $20 \mathrm{~m}$. Estos registros permitieron obtener 183 espectros direccionales de oleaje, correspondientes a la ocurrencia de los huracanes Wilma (octubre de 2005), Dean (agosto de 2007) y Rina (octubre de 2011). Fue detectada la simultaneidad de oleaje local y remoto procedente de diferentes direcciones, debido a la presencia de espectros bimodales. Para los 3 eventos, se encontró que la relación entre la celeridad de traslación de los huracanes y la celeridad de grupo de los trenes de olas puede explicar la presencia o ausencia de bimodalidad espectral, ya sea en frecuencia o dirección.

Palabras clave: oleaje, espectro bimodal, huracán, Caribe.

\section{INTRODUCTION}

Waves that are produced by very intense storms are one of the main mechanisms causing short-term morphological transformations in the coastal zone (Silva et al. 2014). Evidence of the short-term variations in beach morphology caused by the passage of hurricane Dean over Cancún, Quintana Roo (Mexico), in 2007 has already been highlighted by Martell-Dubois et al. (2012). A global assessment of the increasing trend in the risk of human losses was carried out in view of the hazards posed by the impact of hurricanes in the coastal zones (Peduzzi et al. 2012). Using the available historical documentation of the trajectories and characteristics of hurricanes that have affected the coasts of the 5 active regions of the world, Weinkle et al. (2012) found that hurricane

\section{INTRODUCCIÓN}

El oleaje generado por tormentas muy intensas es uno de los principales mecanismos detonadores de las trasformaciones morfológicas de corto plazo que tienen lugar en la zona costera (Silva et al. 2014). La evidencia de los cambios a corto plazo ocurridos en la morfología de la playa de Cancún, Quintana Roo (México), como consecuencia del paso del huracán Dean en 2007 ya fue destacada por Martell-Dubois et al. (2012). Por otra parte, también se ha realizado una evaluación a nivel mundial de la tendencia ascendente del riesgo de pérdidas humanas, como consecuencia del peligro que representa el impacto de los huracanes sobre la zona costera (Peduzzi et al. 2012). Tomando como base la documentación histórica disponible relacionada con las trayectorias y las 
damage in coastal zones had increased in recent years. These authors suggested that this increase could be associated with the accelerated increase of infrastructure development near the coastline.

Experts from the Hurricane Research Division of the National Oceanic and Atmospheric Administration (NOAA, USA) provided evidence of increasing hurricane activity in the Caribbean Sea associated with the warm phase of the multidecadal fluctuations in sea surface temperature (Landsea et al. 1999, Goldenberg et al. 2001). This evidence indicates that government officials, emergency managers, and potential victims should be aware of this danger and develop early warning systems.

Blanchon et al. (1997) reported evidence of the destructive effect of hurricane waves on coral reef ecosystems in the Caribbean region. In addition to the negative impacts on marine biodiversity, this destructive effect reduces the capacity of coral reefs to function as natural coastal defense structures (Mariño-Tapia et al. 2014).

Unfortunately, there are still few direct observations of sea state under hurricane conditions both in shallow and transition waters (Kennedy et al. 2010) and in oceanic waters (Oey et al. 2007). This has limited the development, adjustment, and validation of methods for the spectral analysis of sea states associated with these large storms. Wang and Hwang (2001) suggest that a realistic description of these sea states can be attained by the spectral separation of wind sea and swell, which is relevant for scientific and engineering applications.

Young (1998) analyzed a series of 229 scalar spectra obtained during the passage of hurricanes that affected the northeastern coast of Australia. This author found that the spectra measured within a distance up to 8 times the radius of maximum winds of the storm event were unimodal and similar to the spectra obtained under limited fetch conditions. Young (1998) reported that the parametric spectral forms described by the JONSWAP spectrum approximated the data well and attributed this similarity to the effect of nonlinear interactions.

On the other hand, after analyzing directional wave spectra recorded during the passage of hurricanes over the northern coast of Australia, Young (2006) reported that waves in the front quadrants of these storms were dominated by swell, which radiated out from intense wind regions located in the rear quadrants. The author observed no tendency for the spectra to become bimodal in either frequency or direction. Under the observing conditions described by Young (2006), wind duration and fetch could have been insufficient for the development and growth of wind sea. However, the author did find spectra with a smooth directional transition from low to high frequencies.

Aboobacker et al. (2011) analyzed wave data measured in shallow waters during the occurrence of typhoons on the western coast of India and found that the resulting spectra were dominated by SW swell. Nevertheless, Boukhanovsky and Guedes-Soares (2009) observed the presence of bimodal características de los huracanes que han afectado las costas de las 5 regiones activas del mundo, Weinkle et al. (2012) encontraron un crecimiento de los daños provocados por los huracanes en la zona costera durante los últimos años. Estos autores plantean que dicho crecimiento podría estar asociado a un incremento acelerado del desarrollo de infraestructura en zonas próximas al litoral.

Expertos de la División de Investigación de Huracanes (Hurricane Research Division) de la Administración Nacional Oceánica y Atmosférica (NOAA, por sus siglas en inglés; EUA) han presentado evidencias de un incremento de la actividad de los huracanes en el mar Caribe, asociado a la presencia de una etapa cálida de las oscilaciones multidecadales de la temperatura superficial del mar (Landsea et al. 1999, Goldenberg et al. 2001). Estas evidencias indican que los funcionarios del gobierno, los administradores de emergencias y los posibles afectados deben ser conscientes de este peligro y desarrollar sistemas de alerta temprana.

Blanchon et al. (1997) presentaron evidencias del efecto destructivo que el oleaje asociado a los huracanes tiene sobre los ecosistemas de arrecifes coralinos en la región del Caribe. Este efecto, además de repercutir negativamente sobre la biodiversidad marina, reduce la capacidad del arrecife como estructura natural de protección costera (Mariño-Tapia et al. 2014).

Desafortunadamente, aún escasean las observaciones directas de las condiciones del mar bajo la influencia de un huracán, tanto en aguas someras y de transición (Kennedy et al. 2010) como en aguas oceánicas (Oey et al. 2007). Esto ha limitado el desarrollo, ajuste y validación de métodos de análisis espectral de los estados del mar asociados a estas grandes tormentas. Wang y Hwang (2001) plantean que se puede obtener una descripción muy realista de estos estados del mar mediante la separación espectral de los oleajes local y remoto, siendo ello de gran importancia para aplicaciones científicas y de ingeniería.

En esta línea, Young (1998) analizó una serie de 229 espectros escalares registrados durante el paso de huracanes que afectaron la costa noroeste de Australia. Encontró que los espectros medidos dentro de una distancia de hasta 8 veces el radio de vientos máximos del evento eran unimodales y similares a los espectros obtenidos en condiciones de fetch limitado. Young (1998) reportó que las formas paramétricas espectrales descritas mediante el espectro JONSWAP se aproximaron muy bien a sus datos, adjudicando esta similitud al efecto de las interacciones no lineales.

Por otra parte, Young (2006), analizando espectros direccionales de oleaje medidos durante la ocurrencia de huracanes en la costa norte australiana, pudo establecer que, en el oleaje de los cuadrantes delanteros de dichos eventos, predominaba el oleaje remoto, irradiado desde las regiones de vientos fuertes ubicadas en los cuadrantes traseros. En sus observaciones, Young (2006) no encontró indicios de que los espectros pudieran convertirse en bimodales ni en frecuencia ni en dirección. Bajo las condiciones de observación descritas 
waves in deep-water records obtained off the Atlantic coast of Portugal, and to describe them they developed a model based on numerical optimization techniques using a random linear search algorithm.

Perrie and Resio (2009) found that nonlinear interactions stimulating swell development play an important role in the evolution of swell in oceanic regions far from the point of origin. But these nonlinear interactions are slower than local interactions taking place in the wave-generation area. These authors also found that interactions between wind sea components were greater than the interactions between wind sea and swell, which could explain the presence of bimodal waves. Perrie and Resio (2009) presented a bimodal wave spectrum (in frequency and direction) measured during the passage of Hurricane Wilma off the coast of Duck, North Carolina. More recently, Hu and Chen (2011) found bimodal spectra in 15\% of the directional spectra analyzed from hurricane wave data measured in deep waters from the Gulf of Mexico and within a range 8 times the radius of maximum winds of the storm. These authors observed 3 types of bimodal directional spectra in the 2 front quadrants of the hurricane. The bimodal spectra found by $\mathrm{Hu}$ and Chen (2011) were (1) far from the hurricane, at a distance 6 to 8 times the radius of maximum winds; (2) bimodal in frequency with significant differences in direction; and (3) bimodal in frequency with same wave direction.

There seems to be incongruity in the results reported by Young $(1998,2006)$ with respect to the presence or absence of bimodal waves in areas affected by hurricanes. The objective of the present study is to present and analyze bimodal wave (sea and swell) data collected during the passage of hurricanes over the Caribbean coast of Mexico. For this, 183 directional spectra measured during hurricanes Wilma (October 2005), Dean (August 2007), and Rina (October 2011) were analyzed (Fig. 1).

Hurricane Wilma has been one of the most powerful meteorological phenomena affecting the Caribbean coast of Mexico in the past 70 years. The destructive effects of Wilma on the coastal infrastructure were so intense because of its slow and erratic movement, with gale-force winds recorded for over 50 consecutive hours off the coast of the Yucatan Peninsula. Some of the records reported by Silva-Casarín et al. (2009) include the most intense wind gust, with $210 \mathrm{~km} \cdot \mathrm{h}^{-1}$, ever reported by the automatic weather station in Cancún and a 24-h rainfall accumulation of 1,576 mm reported by the automatic weather station in Isla Mujeres, Quintana Roo. For Hurricane Wilma, which reached category 5 in the Saffir-Simpson scale, maximum sustained wind speeds of $176 \mathrm{~km} \cdot \mathrm{h}^{-1}$ and wind gusts of up to $293 \mathrm{~km} \cdot \mathrm{h}^{-1}$ were recorded (Franklin 2008).

Hurricane Dean (category 5) traveled rapidly $\left(30 \mathrm{~km} \cdot \mathrm{h}^{-1}\right)$ and, in a nearly straight path, reached maximum wind gusts of up to $270 \mathrm{~km} \cdot \mathrm{h}^{-1}$. By contrast, Hurricane Rina moved slowly at an average speed of $9 \mathrm{~km} \cdot \mathrm{h}^{-1}$ but grew quickly into a category 3 hurricane, reaching maximum wind gusts of up to $205 \mathrm{~km} \cdot \mathrm{h}^{-1}$. Though these 2 hurricanes had a less severe por Young (2006), tanto los tiempos de influencia de los vientos como el fetch podrían haber sido insuficientes para el desarrollo y el crecimiento del oleaje local. Sin embargo, Young (2006) pudo apreciar espectros con una ligera transición direccional desde las bajas hacia las altas frecuencias.

Durante la ocurrencia de tifones, Aboobacker et al. (2011) analizaron datos de oleaje medidos en aguas someras de la costa oeste de la India y encontraron que los espectros resultantes estaban dominados por el oleaje remoto procedente del SW. Sin embargo, Boukhanovsky y Guedes-Soares (2009) observaron la presencia de oleaje bimodal en registros de aguas profundas obtenidos frente a la costa atlántica portuguesa y, para su descripción, desarrollaron un modelo basado en técnicas de optimización numérica aplicando un algoritmo de búsqueda lineal aleatoria.

Perrie y Resio (2009) encontraron que, en la evolución del oleaje remoto, en el océano abierto, lejos de la zona de generación, las interacciones no lineales que estimulan su desarrollo tienen un papel muy importante. Sin embargo, estas interacciones no lineales ocurren más lentamente que las interacciones locales en el área de generación de oleaje. Estos autores también encontraron que las interacciones entre las componentes del oleaje local son mayores que las interacciones entre el oleaje local y el oleaje lejano, lo cual pudiera ser la causa de la presencia de oleaje bimodal. Perrie y Resio (2009) mostraron un espectro de oleaje bimodal, en frecuencia y dirección, medido durante el paso del huracán Wilma en el océano frente a la costa de Duck, Carolina del Norte. Posteriormente, Hu y Chen (2011) a diferencia de Young (1998 y 2006), encontraron la presencia de espectros bimodales en el 15\% de los espectros direccionales, analizados para registros de oleaje de huracán en el golfo de México, los cuales fueron medidos en aguas profundas y dentro de un espacio de hasta 8 veces el radio de vientos máximos de la tormenta. Estos autores observaron en los 2 cuadrantes delanteros del huracán, en el sentido de avance, la presencia de 3 tipos de espectros direccionales bimodales. Los tipos de espectros bimodales encontrados por $\mathrm{Hu}$ y Chen (2011) fueron (1) lejos del huracán, a una distancia entre 6 y 8 veces el radio de vientos máximos; (2) bimodal en frecuencia con diferencias significativas en la dirección; y (3) bimodal en frecuencia casi con la misma dirección de oleaje.

Parece existir un desacuerdo con los resultados de Young (1998, 2006) respecto a la presencia o no de oleaje bimodal en zonas afectadas por huracanes. El objetivo de este trabajo es la presentación y análisis de registros de oleaje bimodal (local y remoto) generados por huracanes a su paso sobre la zona costera del caribe mexicano. Para ello, se analizaron 183 espectros direccionales pertenecientes a los huracanes Wilma (octubre de 2005), Dean (agosto de 2007) y Rina (octubre de 2011) (Fig. 1).

El huracán Wilma ha sido uno de los fenómenos meteorológicos más poderosos que han afectado el litoral caribeño mexicano en los últimos 70 años. Los efectos destructivos 
impact on the Caribbean coast of Mexico than Wilma, they are the most notable hurricanes in the region after the atypical season of 2005.

\section{MATERIALS AND METHODS}

Directional wave data were recorded with a Nortek Acoustic Wave and Current (AWAC) profiler, which was installed off the coast of Puerto Morelos (Fig. 1). The instrument was installed at $20.7 \mathrm{~m}$ depth; thus, the obtained data were direct wave measurements in transition waters under hurricane conditions (Silva-Casarín et al. 2009). This instrument measured sea surface displacement and orbital velocities near the surface. Directional spectra were obtained from the spatial arrangement of sea surface height measured by each of the 4 beams emitted by the instrument. Wave signals during the study period were measured at 1,024-s intervals every $2 \mathrm{~h}$ and at a 4-Hz sampling frequency (Escalante et al. 2009). Under these recording conditions, 49 records of directional waves were obtained during the passage of Hurricane Wilma between 00:00 on 19 October and 00:00 on 23 October 2005.

The Acoustic Doppler Current Profiler (ADCP, RD Instruments), located at $20.0 \mathrm{~m}$ depth, was another source of wave data (Fig. 1). This instrument has 3 different independent techniques for measuring the spectral distribution of waves derived from the time series of pressure, orbital velocity of particles, and sea surface displacement. Orbital velocities can be measured very close to the surface, where exponential dissipation of wave energy with depth does not reduce the signal, and they can thus be transformed into spectra of sea surface de Wilma sobre la infraestructura ubicada en la costa fueron muy intensos debido a su lento y errático desplazamiento, lo cual implicó que se registraran vientos huracanados por más de 50 horas consecutivas frente a las costas de la península de Yucatán. Algunos de los récords mencionados por Silva-Casarín et al. (2009) para el huracán Wilma son los siguientes: la ráfaga de viento más intensa, con $210 \mathrm{~km} \cdot \mathrm{h}^{-1}$, que ha sido registrada por la estación meteorológica automática de Cancún y la acumulación de 1,576 mm de lluvia en $24 \mathrm{~h}$ reportada por la estación meteorológica automática de isla Mujeres, Quintana Roo. Para el huracán Wilma, que alcanzó la categoría 5 en la escala Saffir-Simpson, se registraron vientos máximos sostenidos de $176 \mathrm{~km} \cdot \mathrm{h}^{-1}$ y ráfagas de hasta $293 \mathrm{~km} \cdot \mathrm{h}^{-1}$ (Franklin 2008).

El huracán Dean, de categoría 5, se desplazó muy rápidamente $\left(30 \mathrm{~km} \cdot \mathrm{h}^{-1}\right) \mathrm{y}$, con una trayectoria casi rectilínea, alcanzó ráfagas de vientos máximos de hasta $270 \mathrm{~km} \cdot \mathrm{h}^{-1}$. Por el contrario, el huracán Rina avanzó lentamente, a $9 \mathrm{~km} \cdot \mathrm{h}^{-1}$ de velocidad promedio, pero creció muy rápidamente hasta llegar a convertirse en un huracán de categoría 3, alcanzando ráfagas de vientos máximos de hasta $205 \mathrm{~km} \cdot \mathrm{h}^{-1}$. Estos 2 huracanes, aunque con menor impacto que Wilma sobre el litoral caribeño mexicano, son los más destacados que han ocurrido en la región después de la temporada atípica de 2005.

\section{MATERIALES Y MÉTODOS}

Los datos de oleaje direccional fueron registrados con un perfilador acústico autónomo de corrientes y oleaje (AWAC,

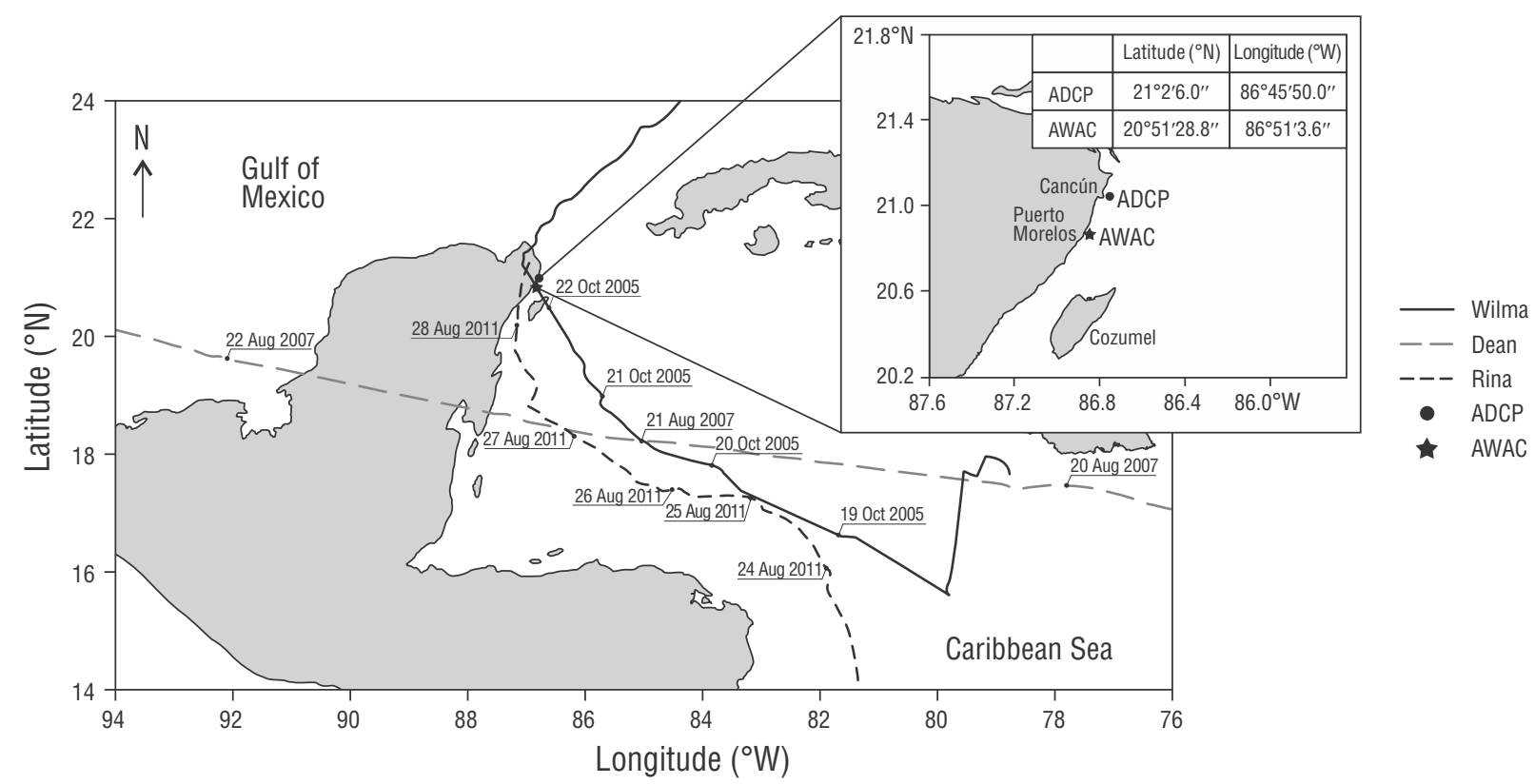

Figure 1. Trajectories for hurricanes Wilma, Dean, and Rina. Location of the AWAC (Nortek) profiler and the ADCP (RDI).

Figura 1. Trayectoria de los huracanes Wilma, Dean y Rina. Ubicación de los perfiladores acústicos AWAC (Nortek) y el ADCP (RDI). 
displacement (Bowden and White 1966). The use of orbital velocities to determine the spectrum is a reliable technique (Nagata 1964). Like the AWAC, ADCP can measure directional spectra.

During the recording period the ADCP was programed to obtain sets of 2,048 samples at $2 \mathrm{~Hz}$ and 1-h intervals. During the passage of Hurricane Dean, 73 wave records were obtained between 00:00 on 20 August and 00:00 on 23 August 2007. By programming the equipment to obtain sets of 2,048 samples at $2 \mathrm{~Hz}$ and 2-h intervals, 61 records of directional waves were obtained during the passage of Hurricane Rina between 00:00 on 24 October and 00:00 on 29 October 2011.

Wind field data and hurricane trajectories were obtained from 2 NOAA sources: (1) the Hurricane Research Division and (2) the National Hurricane center (Pasch et al. 2006; Franklin 2008; NOAA 2008, 2010, 2011; Blake 2012).

It was not always possible to clearly distinguish the simultaneous occurrence of wind sea and swell as 2 well-separated peaks in the wave spectrum. For hurricanes, this distinction is sometimes highly complex because developing wind sea, fully developed wind sea, wind sea transitioning into swell, and fully developed swell can all be found at the same observation site. To separate the wind sea and swell components in the unidimensional spectra, the identification algorithm described by Portilla et al. (2009) was used. The basis for this algorithm is that the energy at the peak frequency of swell cannot be greater than the energy value of the PiersonMoskowitz spectrum for the same frequency. Therefore, if the ratio between the peak energy of the measured waves and the peak energy of the Pierson-Moskowitz spectrum for the same frequency is $>1$, then waves are considered wind sea, otherwise they are considered swell. Wave group celerity was calculated using the linear wave theory approach for intermediate or transition waters (Dean and Dalrymple 1991).

\section{ReSUlts}

\section{Hurricane Wilma (October 2005)}

To quantitatively analyze the temporal evolution of the spectra, the energy density associated with the swell and wind sea modes were calculated for each spectral record by applying the wave partitioning criterion mentioned by Portilla et al. (2009) (Fig. 2). In the beginning, within the first $12 \mathrm{~h}$ on 19 October, there was no swell, only wind sea with low energy levels. From 12:00 onwards swell energy increased until reaching the same wind-sea energy level at 16:00. Wind sea and swell maintained the same energy level until swell energy surpassed wind-sea energy at 00:00 on 20 October. Swell energy increased and decreased at certain intervals, yet it maintained higher levels than wind sea until 06:00 on 22 October. The absolute maximum energy associated with swell occurred at 18:00 on 21 October. At that time the eye of the hurricane was very close to passing over the wave observation site. On 21 October at 18:00 swell energy started to marca Nortek), que se instaló frente a las costas de puerto Morelos (Fig. 1). El equipo se ubicó a una profundidad de $20.7 \mathrm{~m}$, por lo cual los registros obtenidos constituyeron mediciones directas de oleaje en aguas de transición bajo condiciones de huracán (Silva-Casarín et al. 2009). Este equipo permitió medir el desplazamiento de la superficie libre del mar y las velocidades orbitales cerca de la misma. Los espectros direccionales se obtuvieron a partir del arreglo espacial de la altura de la superficie libre del mar medida por cada uno de los 4 haces disparados por el equipo. Durante el periodo de registro, las señales de oleaje se midieron en intervalos de 1,024 s cada $2 \mathrm{~h}$ y con una frecuencia de muestreo de $4 \mathrm{~Hz}$ (Escalante et al. 2009). Con estas características, se obtuvieron 49 registros de oleaje direccional, durante la ocurrencia del huracán Wilma, en el periodo comprendido entre las 00:00 del día 19 y las 00:00 del día 23 de octubre de 2005.

Otra fuente de datos de oleaje fue un Acoustic Doppler Current Profiler (ADCP, RD Instruments), colocado a una profundidad de $20.0 \mathrm{~m}$ (Fig. 1). Este equipo cuenta con 3 técnicas independientes y diferentes para medir la distribución espectral del oleaje mediante series temporales de presión, de velocidades orbitales de las partículas y del recorrido de la superficie. Las velocidades orbitales pueden medirse muy cerca de la superficie, donde la atenuación exponencial de la energía del oleaje con la profundidad no reduce la señal, y así convertirse a espectros superficiales de desplazamiento (Bowden y White 1966). La técnica para determinar el espectro a partir de las velocidades orbitales es confiable (Nagata 1964). El ADCP, al igual que el AWAC, permite la medición de los espectros direccionales.

Durante el periodo de registro, el ADCP se programó para obtener bloques de 2,048 muestras, con una frecuencia de $2 \mathrm{~Hz}$ a intervalos de $1 \mathrm{~h}$. Entre las 00:00 del 20 de agosto de $2007 \mathrm{y}$ las 00:00 del 23 de agosto de 2007 se obtuvieron 73 registros de oleaje durante el paso del huracán Dean. La colocación del equipo, en este caso, programado para obtener bloques de 2,048 muestras, con una frecuencia de $2 \mathrm{~Hz}$ a intervalos de $2 \mathrm{~h}$, permitió obtener 61 registros de oleaje direccional entre las 00:00 del día 24 y las 00:00 del día 29 de octubre de 2011 durante el paso del huracán Rina.

Los datos de los campos de vientos y las trayectorias de los huracanes se obtuvieron de 2 fuentes de la NOAA: (1) Hurricane Research Division y (2) National Hurricane Center (Pasch et al. 2006; Franklin 2008; NOAA 2008, 2010, 2011; Blake 2012).

No siempre es posible distinguir claramente la presencia simultánea de oleaje local y remoto como 2 picos bien separados en el espectro de oleaje. En el caso de los huracanes, esta frontera en ocasiones se torna muy compleja, puesto que es posible tener en el mismo punto de observación oleaje local en desarrollo, oleaje local desarrollado, oleaje en transición de local a remoto y oleaje remoto desarrollado. Para separar las componentes de oleaje remoto y oleaje local en los espectros unidimensionales, se utilizó el algoritmo 

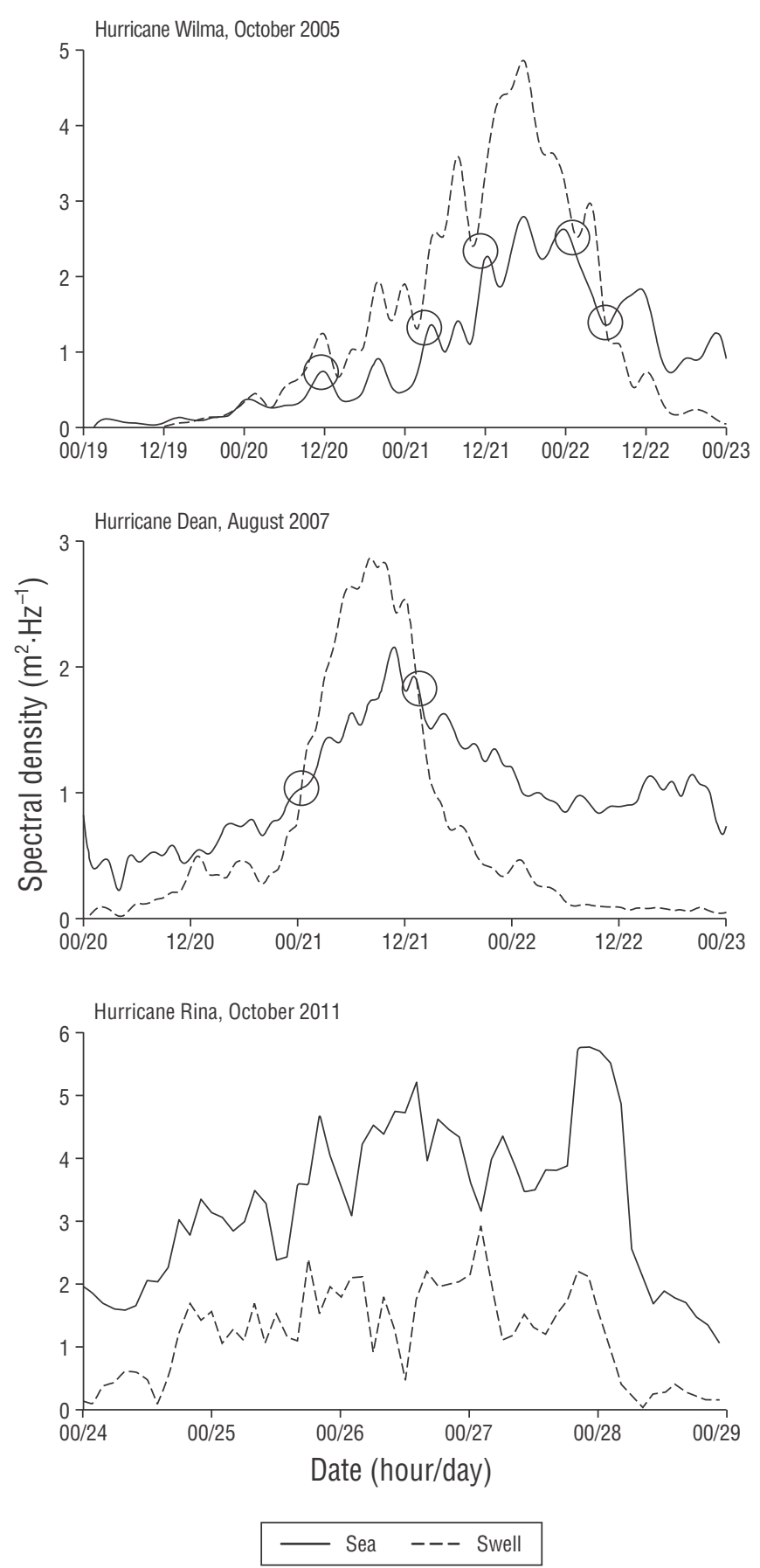

Figure 2. Temporal evolution of energy density associated with swell and wind sea from the spectral records. Circles indicate maximum proximity between swell energy and wind-sea energy.

Figura 2. Evolución temporal de la densidad de energía asociada a los oleajes remoto y local de los registros espectrales. Los círculos reflejan los momentos de máxima aproximación entre las energías de los oleajes local y remoto. de identificación que presentan Portilla et al. (2009). Este algoritmo se basa en que la energía de la frecuencia pico del oleaje remoto no puede ser mayor que el valor de la energía del espectro de Pierson-Moskowitz para la misma frecuencia. Como resultado, se obtiene que si la relación entre el pico de energía del oleaje medido y el del espectro de Pierson-Moskowitz para la misma frecuencia es $>1$ entonces el oleaje se considera local, en caso contrario es remoto. La celeridad de grupo del oleaje fue calculada aplicando la aproximación que provee la teoría lineal del oleaje para las condiciones de aguas intermedias o de transición (Dean y Dalrymple 1991).

\section{RESUltados}

\section{Huracán Wilma (octubre de 2005)}

Para analizar cuantitativamente la evolución temporal de los espectros, se calculó, a partir de la aplicación del criterio referido en Portilla et al. (2009) para la separación de oleaje, para cada registro espectral, la densidad de energía asociada a los modos de oleaje remoto y local (Fig. 2). Inicialmente, en las primeras $12 \mathrm{~h}$ del 19 de octubre, no hubo oleaje remoto, solamente oleaje local y de muy baja energía. A partir de las 12:00, el oleaje remoto comenzó a incrementarse hasta alcanzar a las 16:00 la misma energía del oleaje local. Ambos oleajes se mantuvieron con la misma energía hasta que a partir de las 00:00 del día 20 la energía asociada al oleaje remoto superó a la asociada al oleaje local. La energía del oleaje remoto, a pesar de que presentó intervalos en los que se incrementó y otros en los que disminuyó, se mantuvo superior a la correspondiente al oleaje local hasta las 06:00 del 22 de octubre. El máximo absoluto de la energía asociada al oleaje remoto ocurrió a las 18:00 del 21 de octubre. En ese momento el ojo del huracán se encontraba muy próximo a pasar por encima del punto de observación del oleaje. A partir de las 18:00 del día 21, la energía del oleaje remoto comenzó a reducirse abruptamente, de forma tal que ya a las 06:00 del 22 de octubre se encontraba por debajo de la energía asociada al oleaje local, y a las 00:00 del día 23 había desaparecido casi completamente. La energía asociada al oleaje local también experimentó un crecimiento considerable durante la aproximación del huracán. Nótese que el máximo absoluto de este oleaje coincidió en el tiempo con el máximo de la energía del oleaje remoto. Posteriormente, la energía asociada al oleaje local se redujo lentamente. Finalmente, a las 00:00 del 23 de octubre todavía persistió una cantidad considerable de energía asociada al oleaje local. Ello se debe a que el huracán salió nuevamente al mar (ver trayectoria en Fig. 1), pero en esta ocasión a las aguas del golfo de México rumbo hacia el NE, de manera que a esta hora todavía los vientos locales continuaban siendo intensos, existiendo condiciones favorables para la generación del oleaje local. 
abruptly decrease in such a way that by $06: 00$ on 22 October it was lower than the energy level of wind sea, and by 00:00 on 23 October it had completely disappeared. The energy associated with wind sea also increased considerably as the hurricane moved closer to the observation site. Note that the absolute maximum for wind sea coincided in time with maximum swell energy. The energy associated with wind sea then decreased slowly. Towards the end, at 00:00 on 23 October a considerable amount of energy associated with wind sea was still persistent. This happened because the hurricane turned seaward once again (see path in Fig. 1), this time in a NE direction towards the Gulf of Mexico, and local winds at that time continued to be intense, providing favorable conditions for wind sea.

During the passage of this hurricane the simultaneous occurrence of wind sea and swell at the observation site was recorded, almost throughout the entire duration of the phenomenon. Wind sea and swell showed similar energy levels on 5 occasions as this meteorological phenomenon approached, passed over, and moved away from the observation site (Fig. 2). The result for the analysis of the temporal evolution of the wind-sea and swell energy densities corroborated the presence of bimodality.

The results for the analysis of scalar spectra suggested extending the analysis to include the directional spectra. Together with the surfaces of directional wave spectra, the partial sums of the energy distributions were placed on the bottom surfaces as a function of frequency and direction (Fig. 3). In the beginning, at 00:00 on 19 October (Fig. 3a), only wind sea arriving from the $\mathrm{E}$ was present, with very low energy. Twelve hours later (Fig. 3b), swell became present and showed the same energy distribution as wind sea but with a slightly different direction, both coming from the second quadrant with respect to the N. At 00:00 on 20 October (Fig. 3c), swell energy increased considerably and became the dominant mode, with direction almost entirely from the ESE. Twelve hours later (Fig. 3d), conditions were similar but energy had increased. Wind sea grew conjointly with swell at 00:00 on 21 October (Fig. 3e). Two independent modes were identified for the direction of incidence, one corresponding to swell in the second quadrant and the other to wind sea in the first quadrant. Swell continued coming from the ESE, whereas wind sea had an ENE direction. An identical situation was observed during the $12 \mathrm{~h}$ that followed but with higher energy (Fig. 3f). The analysis of directional spectra confirmed the existence of the spectral bimodality of waves, as wind sea and swell coming from different directions coexisted simultaneously.

By 00:00 on 22 October (Fig. 3g) swell energy slightly decreased, peak frequency increased, and the direction of maximum energy veered SE. Meanwhile, the growth of 3 modes of wind waves coming from different directions, between ESE and ENE, was observed. Twelve hours later (Fig. 3h) swell energy levels decreased, the peak of maximum energy changing to frequencies of $\sim 0.1 \mathrm{~Hz}$ (periods of $\sim 10 \mathrm{~s}$ ),
Durante el paso de este huracán, se registró la presencia de oleaje remoto y oleaje local de forma simultánea sobre el punto de observación, durante casi todo el tiempo de duración del fenómeno. La energía de los oleajes local y remoto presentaron un valor muy cercano entre sí en 5 ocasiones durante la aproximación, paso y retirada de este fenómeno meteorológico (Fig. 2). Este resultado corrobora la bimodalidad a partir del análisis de la evolución temporal de la densidad de energía asociada a los oleajes remoto y local.

Los resultados del análisis de los espectros escalares sugieren la extensión del análisis a los espectros direccionales. Conjuntamente con las superficies de los espectros direccionales, se colocaron en los planos de fondo las sumatorias parciales de las distribuciones de energía en función de la frecuencia y la dirección (Fig. 3). Inicialmente, a las 00:00 del 19 de octubre (Fig. 3a) solo hubo oleaje local, con muy baja energía y procedente del E. Doce horas después (Fig. 3b), comenzó a aparecer el oleaje remoto y, en este momento, presentó una energía similar al local, pero con direcciones de incidencia ligeramente diferentes, las dos provenientes del segundo cuadrante con respecto al N. A las 00:00 del 20 de octubre (Fig. 3c), la energía del oleaje remoto creció considerablemente convirtiéndose en el modo dominante, con una dirección de procedencia casi únicamente del ESE. Doce horas después (Fig. 3d), el cuadro observado fue similar al anterior, pero con un incremento de la energía. Conjuntamente con el crecimiento del oleaje remoto, se observó un crecimiento del oleaje local a las 00:00 del 21 de octubre (Fig. 3e). En cuanto a las direcciones de incidencia, se distinguieron 2 modos independientes, uno correspondiente al oleaje remoto en el segundo cuadrante y otro al oleaje local en el primer cuadrante. En el caso del oleaje remoto, el rumbo de procedencia continuó siendo el ESE y, por su parte, el oleaje local provino del ENE. Una situación idéntica pero con mayor energía se observó en las siguientes 12 h (Fig. 3f). El análisis de los espectros direccionales confirmó la existencia de una bimodalidad espectral del oleaje, al coexistir simultáneamente los oleajes remoto y local procedentes de diferentes direcciones.

Para las 00:00 del 22 de octubre (Fig. 3g), la energía del oleaje remoto se redujo ligeramente, la frecuencia del pico aumentó y la dirección de máxima energía se desplazó hacia el SE. Al mismo tiempo, se observó el crecimiento de 3 modos de oleaje local provenientes de 3 direcciones diferentes entre el ESE y el ENE. Doce horas después (Fig. 3h), el oleaje remoto se redujo, transfiriéndose el pico de máxima energía a frecuencias de alrededor de $0.1 \mathrm{~Hz}$ (periodos de alrededor de los 10 s), y la dirección del oleaje local pasó a estar entre el SE y el S. A estas horas el huracán ya se alejaba con rumbo NE hacia el golfo de México, pero debido a la gran extensión espacial alcanzada por este sistema, aun los vientos de su porción sur continuaron afectando de manera local las aguas del punto de observación y generando oleaje local.

La comparación entre la evolución temporal de la celeridad de traslación del ojo del huracán y la evolución temporal de 
a

00:00 19 October 2005

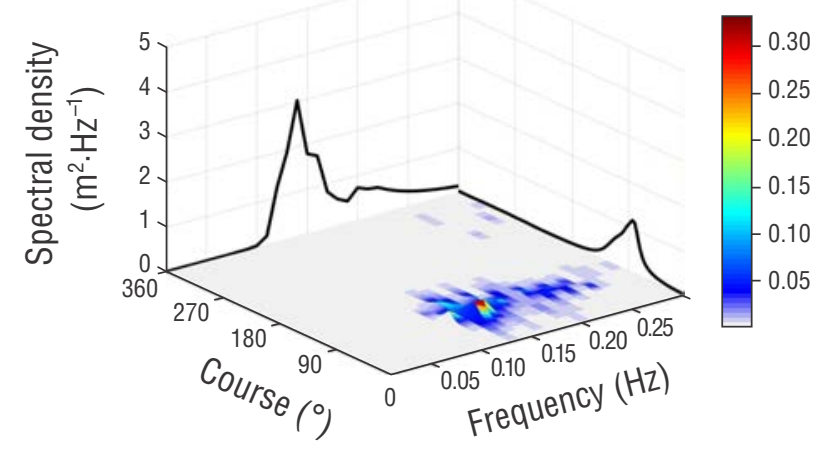

C

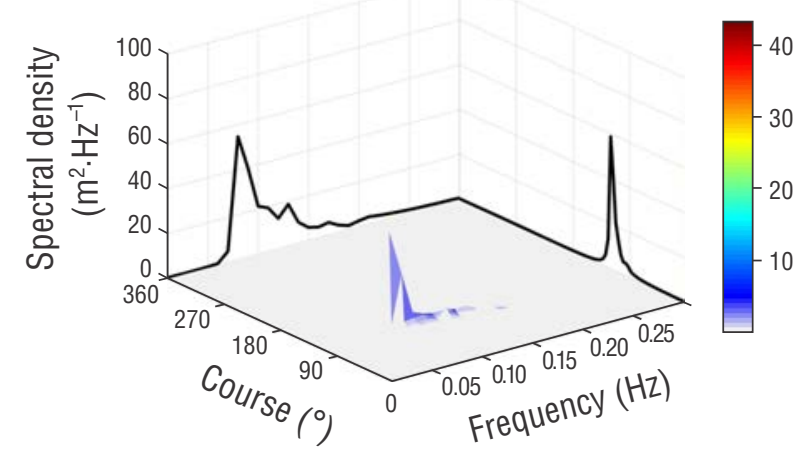

e

00:00 21 October 2005

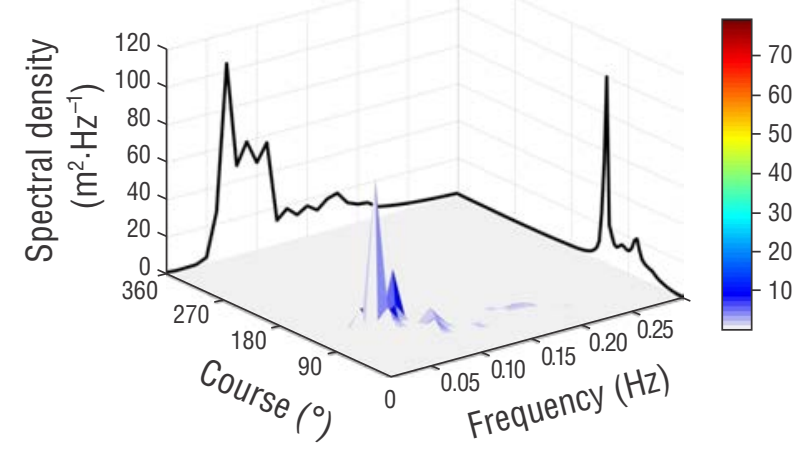

g

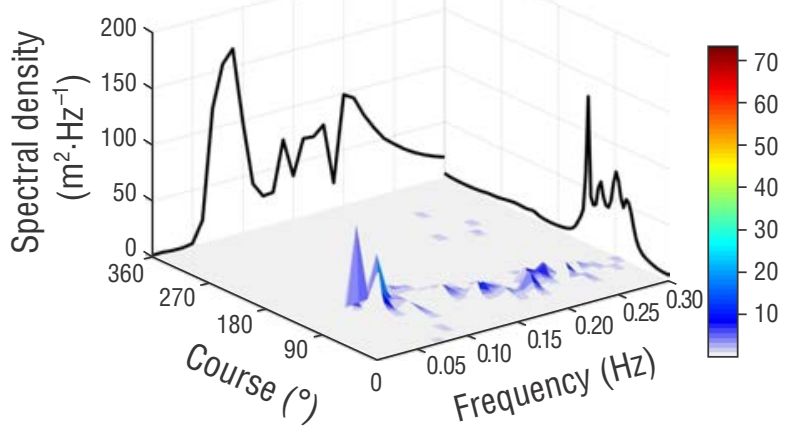

b

12:00 19 October 2005

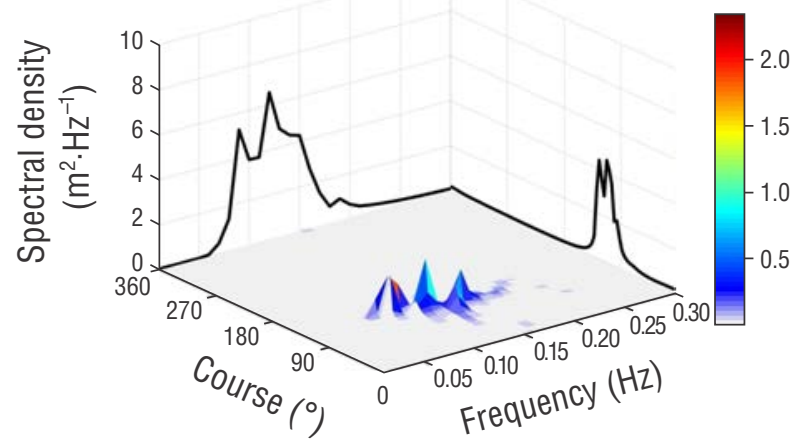

d

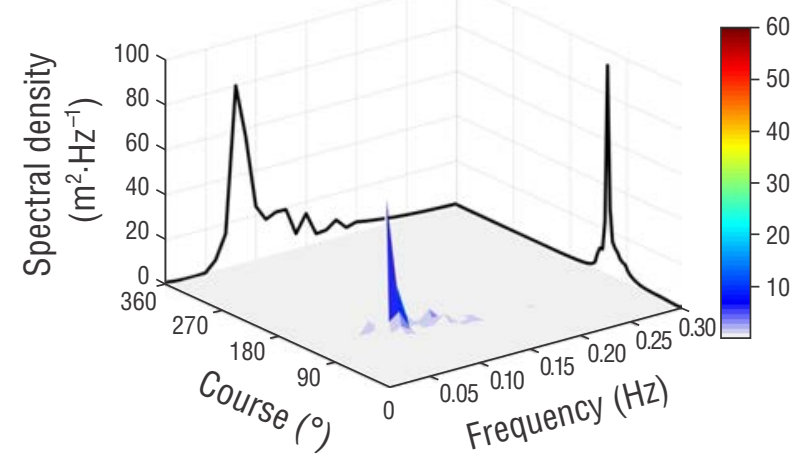

f

12:00 21 October 2005

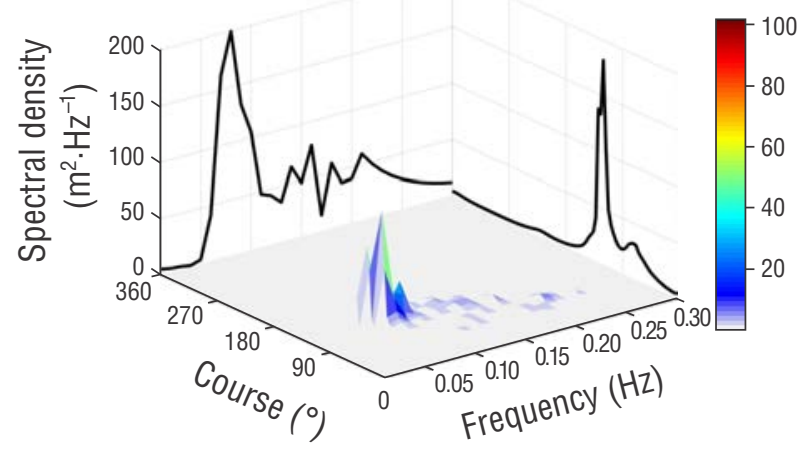

h

12:00 22 October 2005

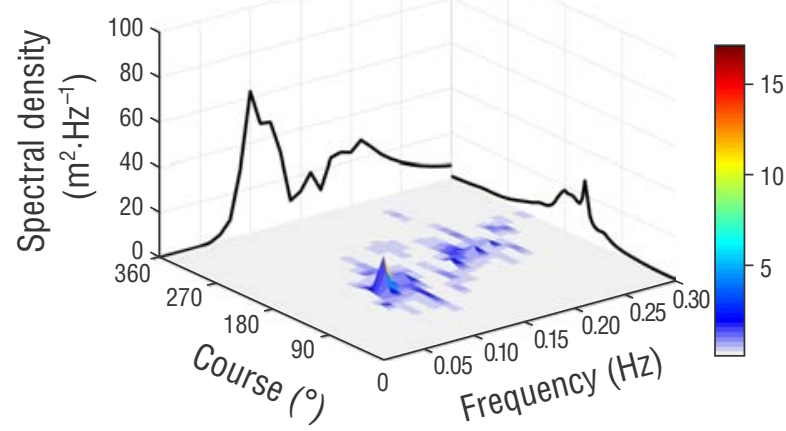

Figure 3. Directional spectra recorded on 19-20 October 2005 (Hurricane Wilma).

Figura 3. Espectros direccionales registrados entre el 19 y 20 de octubre de 2005 (huracán Wilma). 
and the direction of wind sea was between SE and S. At that time the hurricane had already moved away in a NE direction towards the Gulf of Mexico but given the large spatial extension of this system, winds on its southern portion continued to locally affect waters at the observation site and to generate wind sea.

The comparison between the temporal evolution of the translational speed of the eye of the hurricane and the temporal evolution of wave group celerity enabled a description of the possible causes of bimodality in frequency and direction (Fig. 4). Wave group celerity turned out to be similar to the translational speed of the hurricane throughout most of the recording period, thus providing the time needed for wind-sea growth and development.

\section{Hurricane Dean (August 2007)}

To quantitatively analyze the temporal evolution of the spectral energy of waves associated with this hurricane, energy density associated with swell and wind sea was calculated for each spectral record, as was done for Hurricane Wilma (Fig. 2). Wind sea dominated the spectrum most of the time; swell exceeded wind sea only between 00:00 and 13:00 on 21 August. It was during this time that the eye of the hurricane was closest to the observation site. Before and after this period swell energy was almost insignificant when compared with energy associated with wind sea.

The analysis of 6 directional spectra corresponding to Hurricane Dean between 20 and 22 August 2007, allowed the detection of spectral bimodality (Fig. 5). On 20 August at 10:00 (Fig. 5a) the presence of wind sea and swell, both from the ESE, was observed with similar and spectrally distinguishable peak heights. Later on at 00:00 on 21 August (Fig. 5b), the peak for swell increased, covering a dominant portion of the spectrum over wind sea, and the prevailing direction was SE. In this record wind sea and swell were still spectrally distinct. By that time the hurricane had reached category 5 in the Saffir-Simpson scale, with maximum sustained winds of $270 \mathrm{~km} \cdot \mathrm{h}^{-1}$. At 10:00 on 21 August (Fig. 5c) the eye of the hurricane made landfall and reached maximum proximity to the observation site, with wind sea considerably growing to a point where peak wave height matched swell height. Wave direction was still SE. By then wind sea and swell showed considerable overlap. At 14:00 (Fig. 5d), the distribution of energy was similar in frequency and direction, but there was less energy. At 02:00 on 22 August (Fig. 5e), swell energy began to decay with respect to wind-sea energy, but both continued to overlap and wave direction was still SE. Finally, at 16:00 (Fig. 5f) there was a decrease in swell and the direction of the wind-wave peak changed to the E. Between 10:00 on 20 August (Fig. 5a) and 10:00 on 21 August (Fig. 5c) asymmetry in the directional energy distribution was notable. Even when the dominant peak was in the second quadrant, an important amount of energy from the first quadrant was recorded. la celeridad de grupo del oleaje permitió describir las posibles causas de la bimodalidad en frecuencia y dirección (Fig. 4). El hecho de que la celeridad de grupo del oleaje resultó muy similar a la celeridad de traslación del huracán, durante casi todo el tiempo de registro, proporcionó el tiempo requerido para el desarrollo y crecimiento del oleaje local.

\section{Huracán Dean (agosto de 2007)}

Para analizar cuantitativamente la evolución temporal de la energía espectral del oleaje asociado a este huracán, de forma análoga a lo realizado para el huracán Wilma se calculó, para cada registro espectral, la densidad de energía asociada a los oleajes remoto y local (Fig. 2). El oleaje local dominó el espectro la mayor parte del tiempo, siendo superado por el oleaje remoto únicamente entre las 00:00 y las 13:00 del 21 de agosto. Estas son precisamente las horas durante las cuales el ojo del huracán estuvo más próximo al punto de observación. Antes y después de este periodo, la energía asociada al oleaje remoto resultó casi despreciable frente a la correspondiente al local.

El análisis de 6 espectros direccionales de oleaje correspondientes al huracán Dean entre el 20 y 22 de agosto de 2007 permitió identificar la presencia de bimodalidad espectral (Fig. 5). A las 10:00 del 20 de agosto (Fig. 5a) se observó la presencia de los oleajes local y remoto, ambos procedentes del ESE, con alturas de pico similares y muy bien diferenciadas espectralmente. Posteriormente, a las 00:00 del 21 de agosto (Fig. 5b), el pico de oleaje remoto creció y se estrechó dominando el espectro sobre el oleaje local presente, y la dirección predominante pasó a ser del SE. Para este registro, los oleajes local y remoto continuaron estando bien separados espectralmente. En este momento el huracán había alcanzado la categoría 5 en la escala de Saffir-Simpson con vientos máximos sostenidos de $270 \mathrm{~km} \cdot \mathrm{h}^{-1}$. A las 10:00 del 21 de agosto (Fig. 5c), el ojo del huracán había tocado tierra y alcanzado su máxima proximidad al punto de observación, propiciando esto un crecimiento considerable del oleaje local, al punto de equipararse la altura de su pico a la del oleaje remoto. La dirección de procedencia del oleaje continuó siendo el SE. Para este momento, hubo un importante grado de solape entre el oleaje local y el oleaje remoto. A las 14:00 del 21 de agosto (Fig. 5d), la distribución energética en frecuencia y dirección se mantuvo similar, pero con menor energía. A partir de las 02:00 del 22 de agosto (Fig. 5e), la energía del oleaje remoto comenzó a disminuir respecto a la del local, manteniéndose el solape entre ambas, y la dirección de procedencia del oleaje continuó siendo predominantemente del SE. Finalmente, a las 16:00 (Fig. 5f), el oleaje remoto se redujo significativamente y la dirección del pico del oleaje local cambió hacia el E. Entre las 10:00 del día 20 (Fig. 5a) y las 10:00 del día 21 de agosto (Fig. 5c) se observó una notable asimetría en la distribución energética direccional. Aun cuando el pico dominante estuvo sobre el 

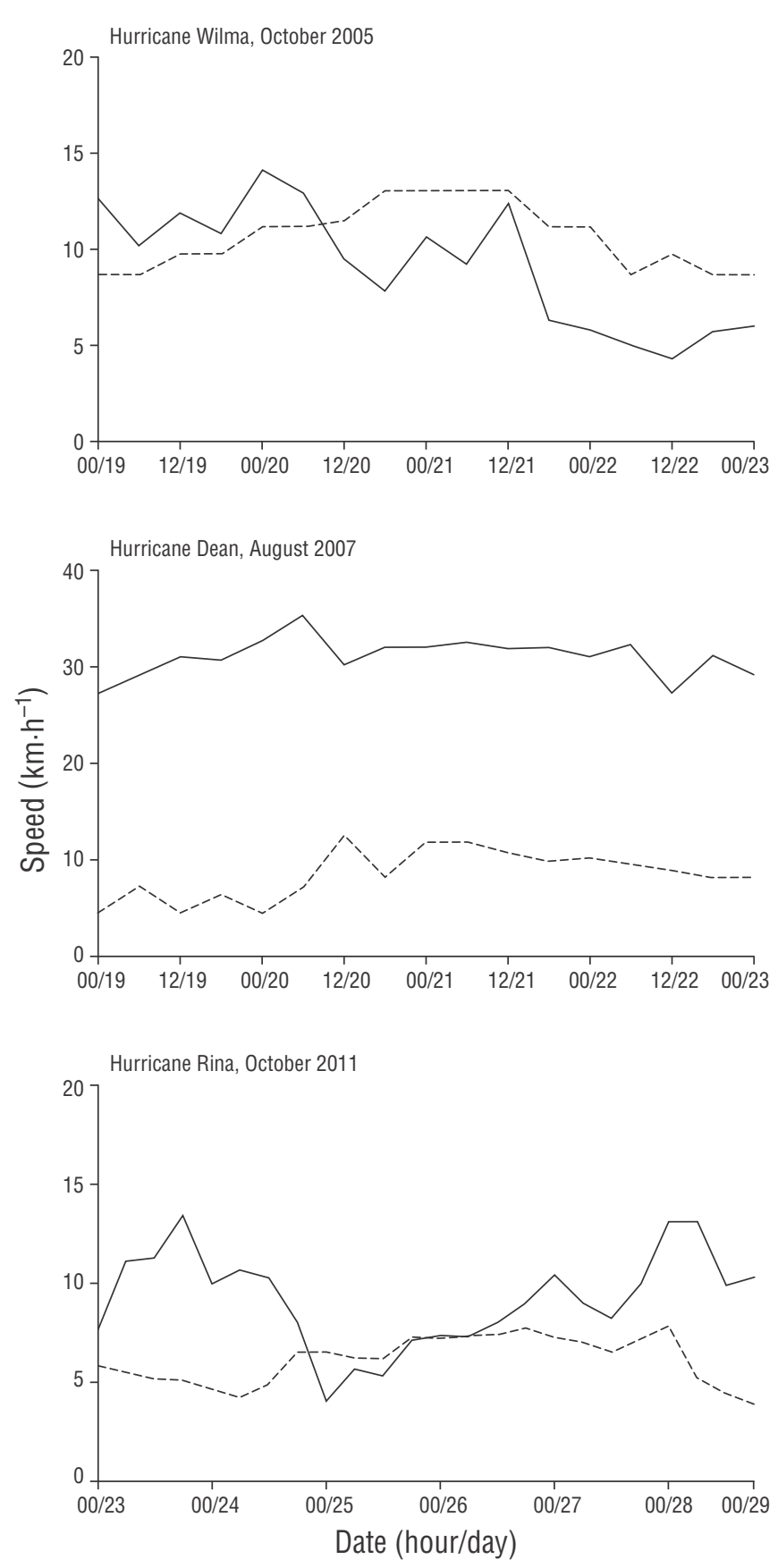

_ Hurricane translational speed _-- Wave group celerity

Figure 4. Temporal evolution of the translational speed of the hurricanes and wave group celerity.

Figura 4. Evolución temporal de la celeridad de traslación de los huracanes y la celeridad de grupo del oleaje. segundo cuadrante, se registró una cantidad importante de energía proveniente del primer cuadrante.

Por tanto, se encontró bimodalidad para este huracán en el ámbito de las frecuencias, pero no en el de las direcciones. Comparando la celeridad de traslación del huracán con la celeridad de grupo del oleaje, se encontró que la celeridad de traslación del huracán Dean fue superior durante todo el recorrido del huracán (ver Fig. 4).

\section{Huracán Rina (octubre de 2011)}

Los cálculos de las distribuciones temporales de la densidad de energía para los oleajes local y remoto registrados durante el paso del huracán Rina indicaron la existencia de un oleaje bimodal (ver Fig. 2). Para este evento, la densidad espectral de energía del oleaje local superó a la correspondiente al oleaje remoto durante todo el tiempo del registro.

El huracán Rina tuvo una corta vida. Se formó el 23 de octubre a las 21:00 (GMT), y 120 h después ya se había disipado totalmente. Recorrió una distancia total de $1,317.1 \mathrm{~km}$, con una celeridad de traslación máxima de $13.45 \mathrm{~km} \cdot \mathrm{h}^{-1}$. Las condiciones de la atmósfera superior, donde existía un fuerte campo de vientos divergentes, y las altas temperaturas del mar Caribe propiciaron un rápido desarrollo de este sistema tropical, de forma tal que a las 09:00 del 25 de octubre el huracán ya había alcanzado la categoría 2.

Al igual que para los huracanes analizados anteriormente, los espectros direccionales asociados a este fenómeno permitieron evaluar de forma conjunta la evolución espectral del oleaje, tanto en el dominio de la frecuencia como en el de las direcciones (Fig. 6). A las 08:00 del 24 de octubre (Fig. 6a), el oleaje presente fue monomodal de tipo local y provino mayoritariamente del primer cuadrante a pesar de tener su pico ubicado en la dirección E. Hacia las 20:00 del mismo día (Fig. 6b), el oleaje ya era bimodal en frecuencia, pero monomodal en la dirección con el máximo espectral proveniente del $\mathrm{E}$ y repartido casi por igual entre el primer y el segundo cuadrante. A las 08:00 del 25 de octubre (Fig. 6c), el oleaje continuó siendo bimodal en frecuencia y también se notó ligeramente bimodal en dirección, pero en ambos casos se apreció un amplio grado de solape entre ambos modos. El oleaje local provino del primer cuadrante con su máximo en el ENE, y el oleaje remoto provino del segundo cuadrante con su máximo en el ESE. Un día después, a las 08:00 del 26 de octubre (Fig. 6d), los picos de los oleajes local y remoto en el ámbito de las frecuencias tuvieron alturas similares, y se separaron e hicieron más pronunciados. En ese momento el oleaje provino mayoritariamente del segundo cuadrante con su máximo pico en la dirección SE. A las 20:00 del día 27 de octubre (Fig. 6e), durante la máxima aproximación del ojo del evento al punto de observación, el oleaje continuó siendo bimodal en frecuencia, pero la altura del pico de oleaje local rebasó considerablemente a la correspondiente al remoto. El pico 
For this hurricane, bimodality was found in the frequency domain but not in direction. The comparison between the translational speed of the hurricane and wave group celerity indicated that the translational speed of hurricane Dean was greater at all times, up to 3 times greater throughout most of the hurricane path (see Fig. 4).

\section{Hurricane Rina (October 2011)}

The results for the temporal distributions of energy density for the wind sea and swell records during the passage of Hurricane Rina indicated the existence of bimodal waves (see Fig. 2). For this event the spectral energy density of wind sea surpassed that of swell during the recording time.

Hurricane Rina was short-lived. It formed on 23 October at 21:00 (GMT), and $120 \mathrm{~h}$ later, it had completely dissipated. This hurricane traveled a total distance of $1,317.1 \mathrm{~km}$, with maximum translational speed of $13.45 \mathrm{~km} \cdot \mathrm{h}^{-1}$. The conditions in the upper atmosphere, which included a strong divergent wind field, and the high temperatures in the Caribbean Sea contributed to the rapid development of this tropical system, to such a degree that the storm had reached category 2 by 09:00 on 25 October .

As was done for the previously analyzed hurricanes, the directional spectra associated with this phenomenon allowed the joint evaluation of the spectral evolution of waves in the frequency and direction domains (Fig. 6). At 8:00 on 24 October (Fig. 6a) waves were unimodal and locally generated, radiating out mainly from the first quadrant in spite of the direction of the peak being E. By 20:00, on the same day (Fig. 6b), waves were already bimodal in frequency but unimodal in direction, with the spectral maximum from the $\mathrm{E}$ and almost equally distributed between the first and second quadrants. At 08:00 on 25 October (Fig. 6c), waves continued to be bimodal in frequency and slightly bimodal in direction, but in both cases a high degree of overlap was observed between both modes. Wind sea originated in the first quadrant, with the maximum in the ENE, and swell originated in the second quadrant, with the maximum in the ESE. The day after, on 26 October at 08:00 (Fig. 6d), the peaks for wind sea and swell had similar heights in the frequency domain, and both became separated and more prominent. At that time waves originated mainly in the second quadrant, with the maximum peak in the SE direction. On 27 October at 20:00 (Fig. 6e), during maximum proximity of the eye of the hurricane to the observation site, waves continued to be bimodal in frequency, but the peak height of wind sea considerably surpassed that of swell. The peak of maximum energy in the directional component came from the SE, though a second peak of wind sea coming from the $E$ was also observed. The hurricane dissipated between the late hours of 27 October and the early hours of 28 October, and so did the waves; by 08:00 on 28 October (Fig. 6f) swell had dissipated and only wind sea, mostly from the E, was recorded. de máxima energía en la componente direccional provino de dirección SE, aunque también se apreció ligeramente un segundo pico de oleaje local procedente del E. A partir de las últimas horas del día 27 y las primeras horas del día 28, el huracán se disipó rápidamente y también el oleaje, de forma tal que el día 28 a las 08:00 (Fig. 6f) el oleaje remoto desapareció y solamente se registró oleaje local procedente mayoritariamente del E.

La comparación entre la celeridad de grupo del oleaje y la celeridad de traslación del huracán Rina indica que la celeridad de traslación del huracán fue superior o similar a la celeridad de grupo del oleaje durante casi todo el evento (ver Fig. 4). Esto pudo haber estado favoreciendo un predominio de las olas de viento generadas de forma local, sobre la posibilidad de crecimiento del oleaje remoto.

\section{DisCUSIÓN}

Con sensores colocados en aguas de transición del mar Caribe, se registraron 183 espectros direccionales del oleaje bajo condiciones hidrodinámicas de 3 diferentes huracanes. El análisis de estos espectros permitió determinar la intensidad de la energía incidente y su distribución en dirección y frecuencia. Los registros aquí presentados de la incidencia simultánea sobre el punto de observación de oleaje local y remoto, constituyen los primeros reportes de este fenómeno para el área del Caribe.

A diferencia de la ausencia de bimodalidad en frecuencia y dirección reportada por Young $(1998,2006)$ en los huracanes del litoral norte de Australia, los resultados del análisis espectral escalar durante la ocurrencia del huracán Wilma indican que, juntamente con el predominio del oleaje remoto, se agregó de forma simultánea la presencia significativa de oleaje local. Esto pudo originarse por las condiciones de generación de oleaje tan particulares que se manifestaron al paso de este intenso huracán. La baja celeridad de traslación del huracán permitió que se pudieran alcanzar, en el punto de observación, tanto oleajes remoto como local y con una energía significativamente importante. Debido a las grandes dimensiones del huracán Wilma, desde el 19 de octubre a las 12:00, cuando su centro se ubicaba a $582 \mathrm{~km}$ del punto de observación, comenzaron a ser perceptibles vientos huracanados provenientes del cuadrante superior izquierdo del sistema. Esto último, unido a la lenta celeridad de traslación del sistema, estimuló el crecimiento del oleaje local al mismo tiempo y sobre el mismo espacio en que se produjeron las interacciones no lineales que dieron lugar a la formación del oleaje remoto. Este comportamiento creó las condiciones para que, además de la bimodalidad en frecuencias, se presentara una bimodalidad direccional. A diferencia de lo descrito por Walsh et al. (2002) y Young (2006), este análisis direccional confirma la existencia de una bimodalidad espectral del oleaje, al coexistir simultáneamente oleajes remoto y local procedentes de diferentes direcciones. Estos 
a

10:00 20 August 2007

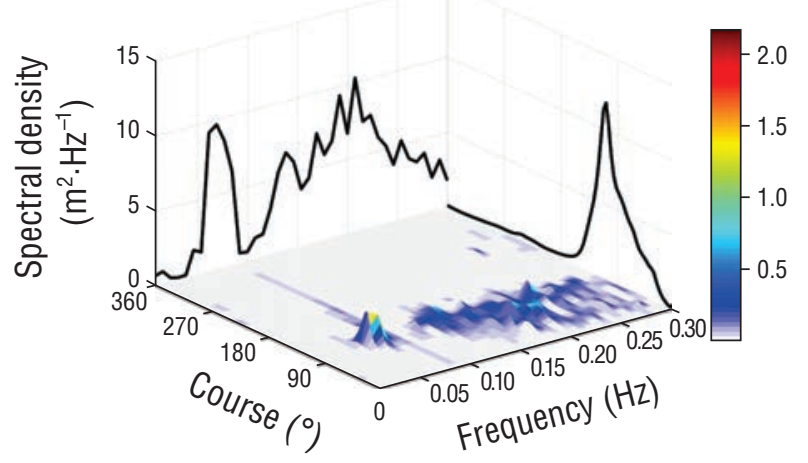

C

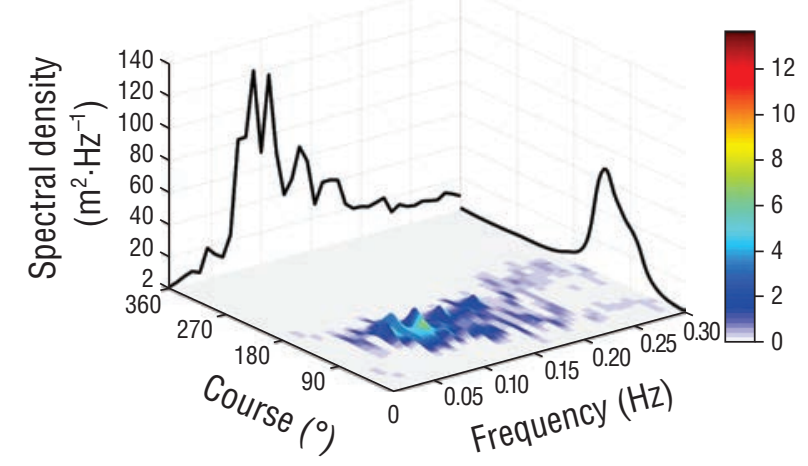

e

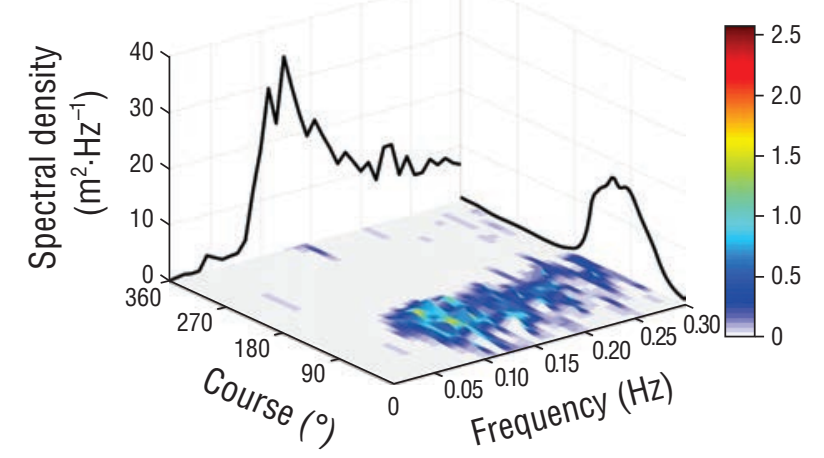

b $\quad 00: 00 \quad 21$ August 2007

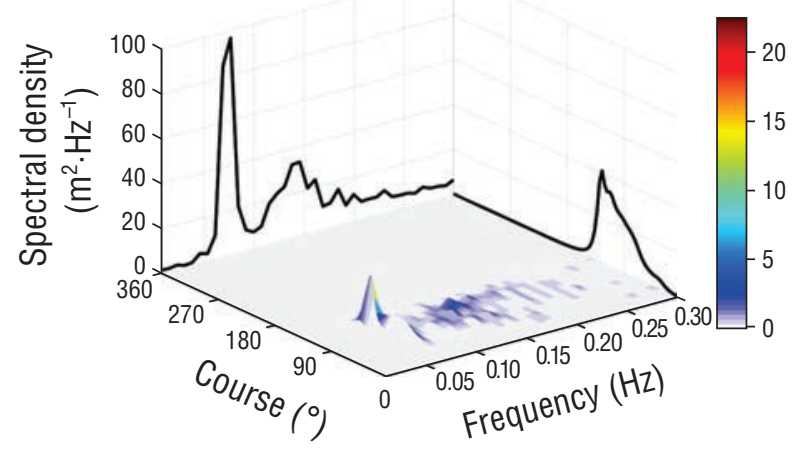

d $\quad$ 14:00 21 August 2007

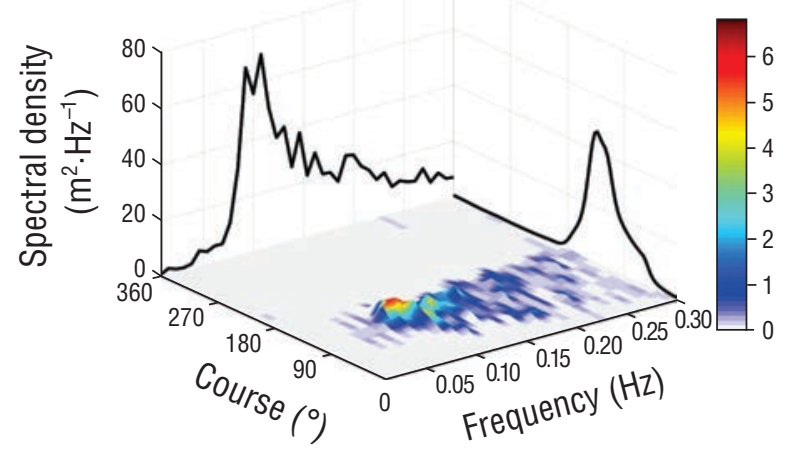

f $\quad$ 16:00 $\quad 22$ August 2007

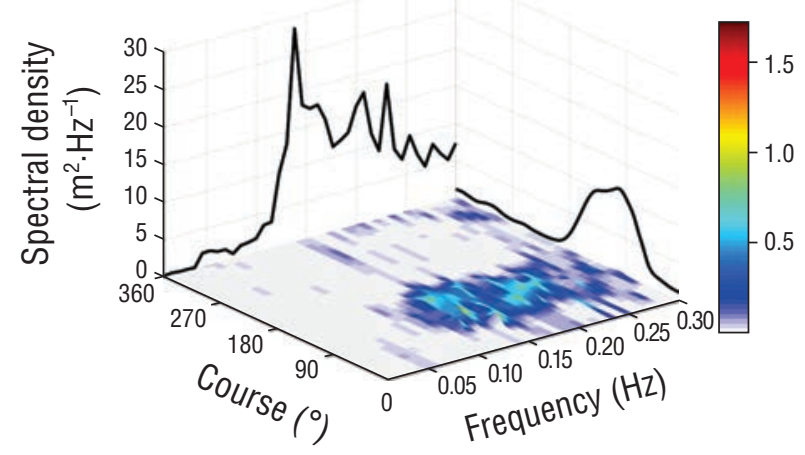

Figure 5. Directional spectra recorded on 20-22 August 2007 (Hurricane Dean).

Figura 5. Espectros direccionales registrados entre el 20 y 22 de agosto de 2007 (huracán Dean).

The comparison between wave group celerity and the translational speed of hurricane Rina indicates that the translational speed of the hurricane was greater or similar to wave group celerity during most of the event (see Fig. 4). This could have favored the dominance of local wind waves over the possible growth of swell.

\section{Discussion}

Sensors placed in transition waters from the Caribbean Sea recorded 183 directional wave spectra under the hydrodynamic conditions of 3 different hurricanes. The analysis resultados se corresponden con las condiciones de bimodalidad propuestas por Perrie y Resio (2009).

En el caso del huracán Dean, el análisis espectral escalar destaca que, tanto para el oleaje local como para el remoto, la energía se incrementó cuando tuvo lugar la máxima aproximación del huracán al punto de observación. Los oleajes remoto y local coexistieron en el mismo sitio, durante el tiempo en que ocurrió la máxima aproximación del huracán al punto de observación. Por una parte, se dan los tiempos y existe la distancia necesaria para la generación del oleaje remoto, de amplitud espectral fina, y por la otra del oleaje local que está generando por los vientos huracanados asociados a la 
a

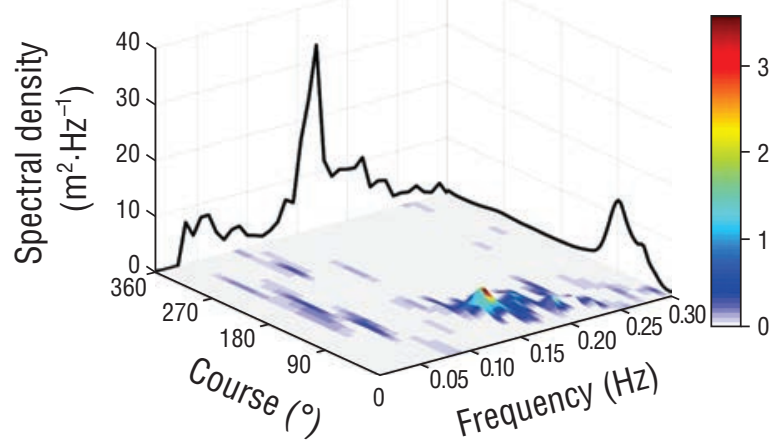

C

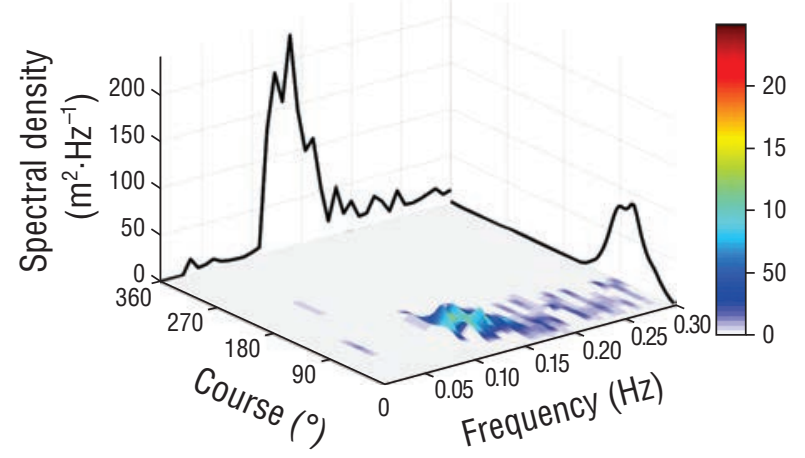

e

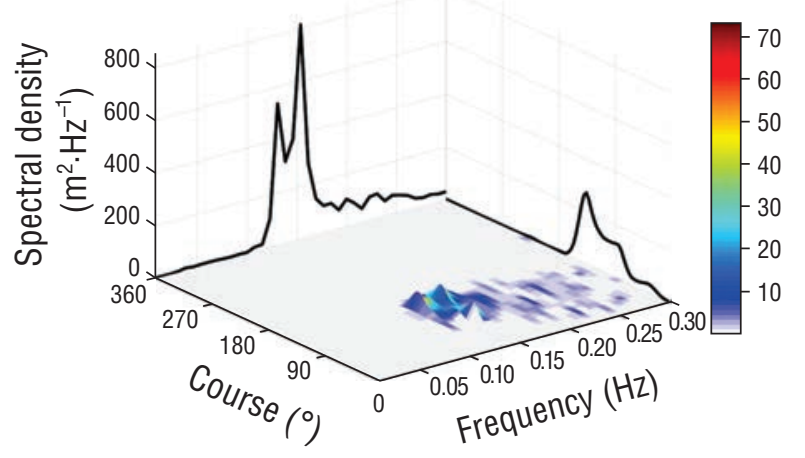

b 20:00 24 October 2011

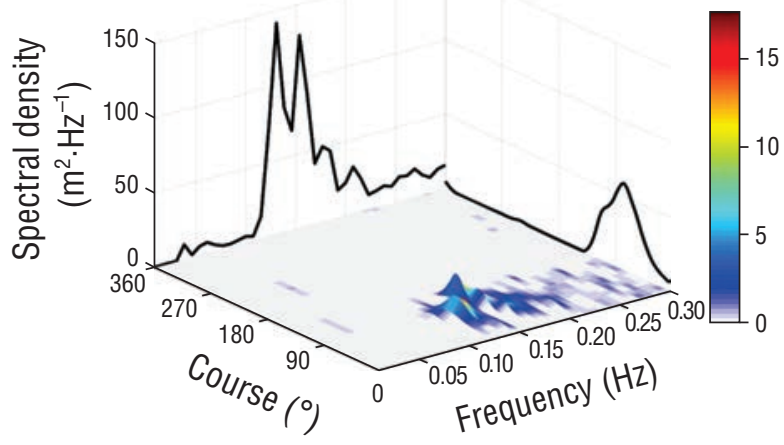

d

08:00 26 October 2011

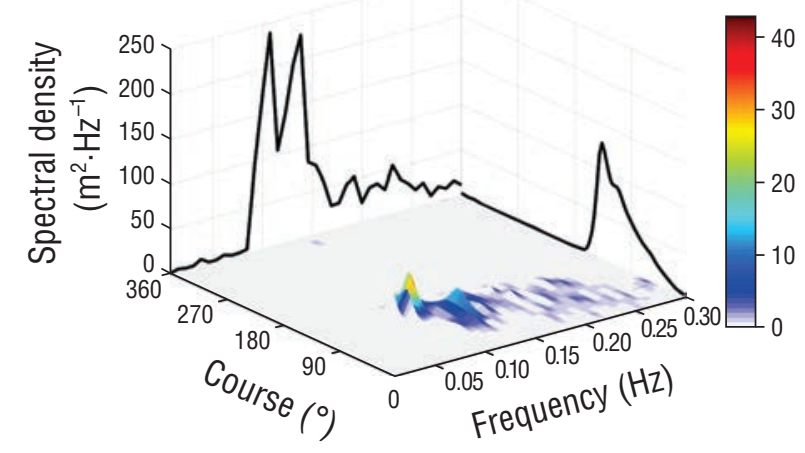

08:00 28 October 2011

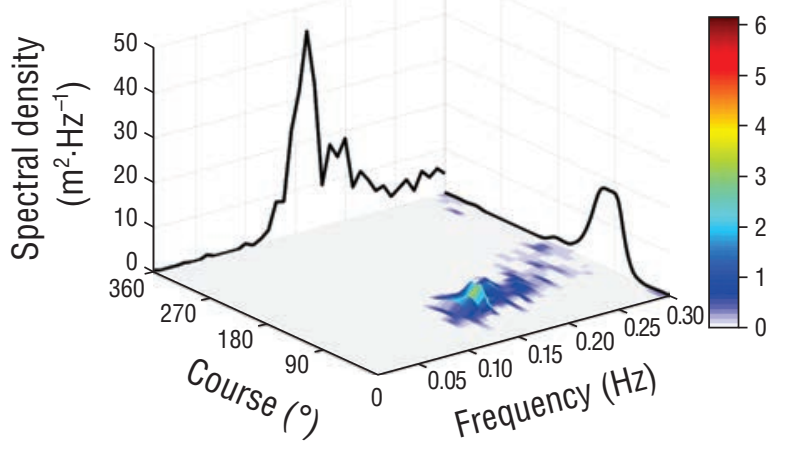

Figure 6. Directional spectra recorded on 24-28 August 2007 (Hurricane Rina).

Figura 6. Espectros direccionales registrados entre el 24 y 28 de agosto de 2007 (huracán Rina).

of these spectra helped determine the intensity of incident energy and its distribution in frequency and direction. The records here indicate simultaneous incidence at the wave observation site and constitute the first reports of this phenomenon for the Caribbean portion.

In contrast with the absence of bimodality in frequency and direction during the passage of hurricanes over the northern coast of Australia (Young 1998, 2006), the scalar spectral analysis for the duration of Hurricane Wilma indicate the predominance of swell and the simultaneous and significant occurrence of wind sea. This could have been caused by the particular way waves were generated during rotación de la masa de aire alrededor del centro de bajas presiones. Al igual que se observó en el caso del huracán Wilma (Fig. 2), en el caso de Dean existieron 2 momentos en los cuales la energía asociada a los oleajes remoto y local fue muy similar, indicando una bimodalidad espectral del oleaje, lo cual satisface las condiciones propuestas por Perrie y Resio (2009).

El análisis de los espectros direccionales del oleaje generado por el huracán Dean demuestra que, a diferencia de lo observado para Wilma, el oleaje generado por este sistema se presentó mayormente de forma monomodal en cuanto a su dirección. Ello podría deberse a que el huracán Dean 
the passage of this intense hurricane. The low translational speed of the hurricane at the observation site allowed wind sea and swell to grow simultaneously and with a significant amount of energy. Due to the large dimensions of hurricane Wilma, gale-force winds blowing from the front left quadrant of the system began to appear at 12:00 on 19 October, when the hurricane center was $582 \mathrm{~km}$ from the observation site. This condition, coupled with the low translational speed of this system, stimulated the growth of wind sea at the same time and in the same space that the nonlinear interactions that generated the swell were taking place. This behavior created the conditions for bimodality not only in frequency but also in direction. Contrary to what was described by Walsh et al. (2002) and Young (2006), this directional analysis confirms the existence of bimodal wave spectra, since wind sea and swell from different directions coexisted simultaneously. These results coincide with the bimodality requirements proposed by Perrie and Resio (2009).

For hurricane Dean the scalar spectral analysis showed that, for both wind sea and swell, energy increased when the hurricane was at maximum proximity to the observation site. Wind sea and swell coexisted in the same space during the time the hurricane was at its maximum proximity to the observation site. The required fetch and duration were present for, one, the generation of swell with small spectral amplitudes and, two, the generation of wind sea by gale-force winds associated with the rotation of the air mass around the low-pressure center. As in the case of Hurricane Wilma (Fig. 2), during Hurricane Dean there were 2 moments in which the energy associated with wind sea and swell was very similar, indicating wave spectral bimodality and thus fulfilling the requirements proposed by Perrie and Resio (2009).

The analysis of the directional wave spectra for Hurricane Dean showed that, unlike that observed for Wilma, waves generated by this system were mostly unimodal in direction. This could be due to the fact that Hurricane Dean moved very rapidly in a straight path from the $\mathrm{E}$ (in a direction almost perpendicular to the coasts of Mexico), whereas Wilma approached the observation site from the $\mathrm{S}$ and in a more erratic way. The high translational speed and linear movement of Hurricane Dean as it approached the observation site could have played a significant role in the generation of unimodal waves, with respect to direction.

Hurricane Rina, on the other hand, formed rapidly and dissipated in just 3 days. These particular conditions significantly influenced wave generation and propagation, and they are reflected in the resulting scalar spectral distributions. Swell developed intermittently and did not consolidate, nor did it dominate the spectrum (see Fig. 2). In contrast with the observations for Wilma and Dean, the ocean-atmosphere interactions associated with the local gale-force winds during the passage of Rina had a prevailing effect on the waves recorded at the observation site. This conditioned the presence of bimodal waves, in the frequency domain, during practically the entire life span of this phenomenon, as was the case for se movió muy rápidamente sobre una trayectoria rectilínea desde el E (en dirección casi perpendicular a las costas de México), mientras que Wilma se aproximó desde el $\mathrm{S}$ hacia el punto de observación y de una forma más errática. La elevada velocidad de desplazamiento del huracán Dean conjuntamente con la linealidad de su aproximación pudieron haber desempeñado un papel significativo en la generación de oleaje monomodal en cuanto a la dirección.

Por otro lado, el huracán Rina se formó muy rápidamente, y en apenas 3 días ya se había disipado. Estas condiciones particulares tuvieron una influencia significativa en el proceso de generación y propagación del oleaje, las cuales se reflejan en las distribuciones espectrales escalares que se obtuvieron. El oleaje remoto se desarrolló de forma intermitente y no alcanzó a consolidarse y dominar el espectro (ver Fig. 2). A diferencia de lo observado para Wilma y Dean, para Rina las interacciones océano-atmósfera asociadas a los vientos huracanados locales tuvieron un efecto prevaleciente en el oleaje registrado en el punto de observación. Ello condicionó la presencia de un oleaje bimodal, en el ámbito de la frecuencia, durante prácticamente todo el tiempo de vida del fenómeno, al igual que ocurría para Wilma y Dean, aunque siempre dominado por las olas de viento. Rina, al igual que Wilma y a diferencia de Dean, se aproximó al punto de observación desde una dirección cercana al S. Los espectros indican que, aunque Rina fue mayoritariamente monomodal con respecto a la dirección, hubo una ligera bimodalidad direccional en algunos momentos, ocupando este fenómeno una posición intermedia entre los huracanes Wilma y Dean.

La mayoría de las observaciones realizadas para los 3 eventos fueron hechas desde una distancia inferior a 8 veces el radio de vientos máximos de los eventos. Además, la bimodalidad se observó en los 2 cuadrantes ubicados a la izquierda del centro del huracán, en el sentido de avance. Con todo lo anterior, se estaría cumpliendo la condición planteada por Hu y Chen (2011) para la posible ocurrencia de bimodalidad.

Los 3 eventos tuvieron características diferentes en cuanto a su génesis y evolución. Como se ha visto a lo largo de la discusión, otro elemento a considerar es la relación entre las celeridades de traslación del fenómeno $\left(V_{\mathrm{T}}\right)$ y las celeridades de grupo $\left(c_{\mathrm{g}}\right)$ de los trenes de olas generados a su paso. Ello sugiere la creación de un índice adimensional $V$, el cociente entre ambas velocidades:

$$
V(t)=\frac{V_{\mathrm{T}}(t)}{c_{g}(t)}
$$

Para los 3 eventos estudiados, resultó interesante la posible influencia del índice $V$ sobre la presencia o no de bimodalidad ya sea en frecuencia o en dirección. Este índice refleja que, para valores próximos a uno, están dadas las condiciones para que ocurra una bimodalidad tanto en frecuencia como en dirección. Con valores en el rango de 1.0 a 2.5, podrían ocurrir 
Wilma and Dean, though wind waves always dominated the spectrum. Like Wilma, yet unlike Dean, Rina approached the observation site from a direction near the $\mathrm{S}$. The spectra indicate that even though Rina was mostly unimodal in direction, slight directional bimodality was observed at certain times; thus, this phenomenon occupied an intermediate position between hurricanes Wilma and Dean.

Most observations for the 3 events were done from a distance less than 8 times the radius of maximum winds of the events. In addition, bimodality was observed in the 2 front left quadrants of the hurricane center. The above statements fulfill the requirements proposed by $\mathrm{Hu}$ and Chen (2011) for the possible occurrence of bimodality.

The 3 events showed different characteristics with respect to their genesis and evolution. Another element to consider, as evidenced throughout the discussion, is the relation between the translational speed of the phenomenon $\left(V_{\mathrm{T}}\right)$ and the wave group celerity $\left(c_{\mathrm{g}}\right)$ produced during its passage. This calls for the creation of a nondimensional $V$ index, the ratio between the 2 velocities:

$$
V(t)=\frac{V_{\mathrm{T}}(t)}{c_{g}(t)}
$$

For the 3 events, the possible influence of the $V$ index on the presence or absence of bimodality, in frequency or direction, turned out interesting. This index indicates that for values close to 1 , there are favorable conditions for bimodality to occur both in frequency and in direction. For values in the range of 1.0-2.5 bimodality could temporarily occur in frequency and in direction. However, for index values $>2.5$ bimodality could only occur in frequency (Fig. 7).

Few events were evidently analyzed for a criterion or quantitative index to be definitive. The findings presented here are the result of the analysis of the spectral characteristics of 3 significant events. Nevertheless, the obtained results constitute a stepping stone for future research on the role of nonlinear interactions between wave components and their relation to the approaching direction and translational speed of the system. The main limitation for these future investigations is still, as suggested by Kennedy et al. (2010), the lack of wave measurements in shallow and transition waters during intense hurricane conditions.

\section{ACKNOWLEDgMents}

The authors received financial support from the National Council for Science and Technology (Mexico) through its national scholarship fund. CONABIO also provided financial support. Special thanks go to Francisco Ruiz-Rentería from the Instituto de Ciencias del Mar y Limnología at UNAM for his support in obtaining the field data used for this study.

English translation by Claudia Michel-Villalobos

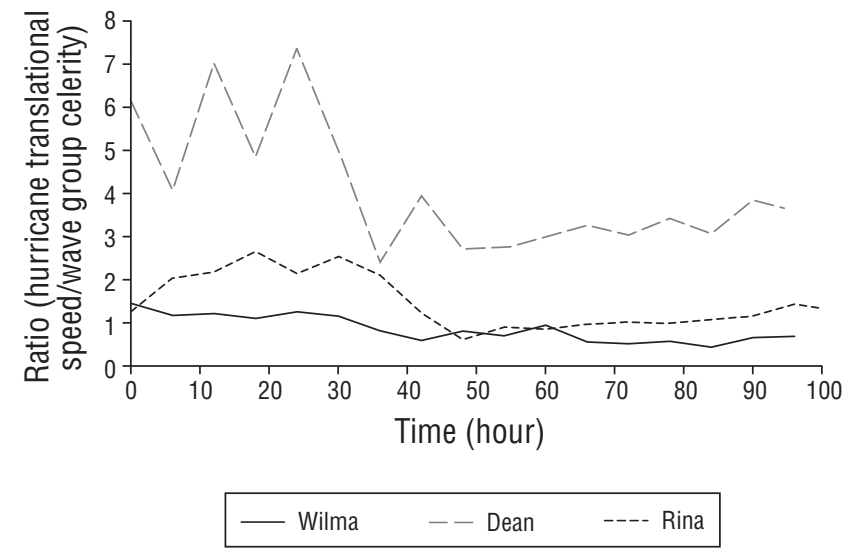

Figure 7. $V$ index values for hurricanes Wilma, Dean, and Rina. Figura 7. Valores del índice $V$ para los huracanes Wilma, Dean y Rina.

de forma temporal tanto la bimodalidad en frecuencia como en dirección. Sin embargo, para valores del índice mayores que 2.5 , se encontró que solo podría ocurrir bimodalidad en frecuencia (Fig. 7).

Evidentemente, son pocos los eventos analizados para emitir un criterio o un índice cuantitativo definitivo. Lo presentado es resultado del análisis de las características espectrales de 3 eventos significativos. Sin embargo, los resultados obtenidos constituyen un punto de partida para continuar profundizando en la comprensión del papel que desempeñan las interacciones no lineales entre las componentes del oleaje, así como su relación con la dirección de aproximación y la celeridad de traslación del sistema. La principal limitación para el futuro de estas investigaciones, como plantean Kennedy et al. (2010), aún continúa siendo la escasez de mediciones de oleaje en condiciones de aguas someras y de transición durante la ocurrencia de huracanes intensos.

\section{Agradecimientos}

Los autores agradecen al Consejo Nacional de Ciencia y Tecnología (México) el apoyo financiero brindado mediante su fondo de becas nacionales para llevar a cabo la presente investigación. Se agradece a la CONABIO el apoyo financiero brindado. Un agradecimiento muy especial a Francisco Ruiz-Rentería del Instituto de Ciencias del Mar y Limnología de la UNAM por el apoyo brindado para la obtención de los datos de campo que sustentan el presente trabajo. 


\section{REFERENCES}

Aboobacker VM, Rashmi R, Vethamony P, Menon HB. 2011. On the dominance of pre-existing swells over wind seas along the west coast of India. Cont. Shelf Res. 31(16): 1701-1712. https://doi.org/10.1016/j.csr.2011.07.010

Blake ES. 2012. Tropical cyclone report: Hurricane Rina (AL182011) 23-28 October 2011 [accessed 14 March 2018]. National Hurricane Center, Miami (FL). https://www.nhc.noaa.gov/data/ tcr/AL182011_Rina.pdf.

Blanchon P, Jones B. 1997. Hurricane control on shelf-edge-reef architecture around Grand Cayman. Sedimentology 44(3): 479-506. https://doi.org/10.1046/j.1365-3091.1997.d01-32.x

Boukhanovsky AV, Guedes-Soares C. 2009. Modelling of multipeaked wave spectra. Appl. Ocean Res. 31(2): 132-141. https://doi.org/10.1016/j.apor.2009.06.001

Bowden KF, White RA. 1966. Measurements of the orbital velocities of sea waves and their use in determining the directional spectrum. Geophys. J. Int. 12(1): 33-54. https://doi.org/10.1111/j.1365-246x.1966.tb03100.x

Dean RG, Dalrymple RA. 1991. Water wave mechanics for engineers and scientists. World Scientific Publishing Company, Singapore, $368 \mathrm{pp}$.

Escalante E, Silva R, Mendoza E, Mariño I, Ruiz F. 2009. Análisis de la variación del nivel del mar y de las corrientes marinas inducidas por el huracán Wilma frente a Puerto Morelos, Quintana Roo, México. Ing. Hidraul. Mex. 24(2): 111-126.

Franklin JL. 2008. Tropical cyclone report: Hurricane Dean (AL042007) 13-23 August 2007 [accessed 14 March 2018]. National Hurricane Center, Miami (FL). https://www.nhc.noaa. gov/data/tcr/AL042007_Dean.pdf

Goldenberg SB, Landsea CW, Mestas-Nuñez AM, Gray WM. 2001. The recent increase in Atlantic hurricane activity: Causes and implications. Science 293(5529): 474-479. https://doi.org/10.1126/science.1060040

Hu K, Chen Q. 2011. Directional spectra of hurricane-generated waves in the Gulf of Mexico. Geophys. Res. Lett. 38(19): LI9608. https://doi.org/10.1029/2011gl049145

Kennedy AB, Gravois U, Zachry B, Luettich R, Whipple T, Weaver R, Reynolds-Fleming J, Chen QJ, Avissar R. 2010. Rapidly installed temporary gauging for hurricane waves and surge, and application to Hurricane Gustav. Cont. Shelf Res. 30(16): 1743-1752. https://doi.org/10.1016/j.csr.2010.07.013

Landsea CW, Pielke RA Jr, Mestas-Nunez AM, Knaff JA. 1999. Atlantic basin hurricanes: Indices of climatic changes. Clim. change 42(1): 89-129. https://doi.org/10.1007/978-94-015-9265-9_9

Mariño-Tapia I, Enriquez C, Silva R, Mendoza-Baldwin E, Escalante-Mancera E, Ruiz-Renteria F. 2014. Comparative morphodynamics between exposed and reef protected beaches under hurrricane conditions. Coast. Eng. Proc. 1(34): 9 pp. https://doi.org/10.9753/icce.v34.sediment.55

Martell-Dubois R, Mendoza-Baldwin E, Mariño-Tapia I, SilvaCasarín R, Escalante-Mancera E. 2012. Impactos de corto plazo del huracán Dean sobre la morfología de la playa de Cancún, México = Short-term impact of Hurricane Dean on the morphology of the beach at Cancun, Mexico. Tecnol. Cienc. Agua 3(4): 89-111.

Nagata Y. 1964. The statistical properties of orbital wave motions and their application for the measurement of directional wave spectra. J. Oceanogr. Soc. Jpn. 19(4): 169-181. https://doi.org/10.5928/kaiyou1942.19.169
[NOAA] National Oceanic and Atmospheric Administration. 2008. Hurricane Research Division: 2005 Hurricane Season [accessed 14 March 2018]. NOAA, Miami (FL). http://www.aoml.noaa. gov/hrd/data_sub/hurr2005.html.

[NOAA] National Oceanic and Atmospheric Administration. 2010. Hurricane Research Division: 2007 Hurricane Season [accessed 14 March 2018]. NOAA, Miami (FL). http://www.aoml.noaa. gov/hrd/data_sub/hurr2007.html.

[NOAA] National Oceanic and Atmospheric Administration. 2011. Hurricane Research Division: 2011 Hurricane Season [accessed 14 March 2018]. NOAA, Miami (FL). http://www.aoml.noaa. gov/hrd/data_sub/hurr2011.html.

Oey L-Y, Ezer T, Wang D-P, Yin X-Q, Fan S-J. (2007) Hurricaneinduced motions and interaction with ocean currents. Continental Shelf Research 27: 1249-1263.

Pasch RJ, Blake ES, Cobb HD III, Roberts DP. 2006. Tropical cyclone report: Hurricane Wilma 15-25 October 2005 [accessed 14 March 2018]. National Hurricane Center, Miami (FL). https://www.nhc.noaa.gov/data/tcr/AL252005_ Wilma.pdf

Peduzzi P, Chatenoux B, Dao H, De Bono A, Herold C, Kossin J, Mouton F, Nordbeck O. 2012. Global trends in tropical cyclone risk. Nat. Clim. Change 2(4): 289-294. https://doi.org/10.1038/nclimate1410

Perrie W, Resio DT. 2009. A two-scale approximation for efficient representation of nonlinear energy transfers in a wind wave spectrum. Part II: application to observed wave spectra. J. Phys. Oceanogr. 39(10): 2451-2476. https://doi.org/10.1175/2009jpo3947.1

Portilla J, Ocampo-Torres FJ, Monbaliu J. 2009. Spectral partitioning and identification of wind sea and swell. J. Atmos. Oceanic Technol. 26(1): 107-122. https://doi.org/10.1175/2008JTECHO609.1

Silva R, Martínez ML, Hesp PA, Catalan P, Osorio AF, Martell R, Fossati M, Miot da Silva G, Mariño-Tapia I, Pereira P, Cienguegos R, Klein A, Govaere G. 2014. Present and future challenges of coastal erosion in Latin America. J. Coastal Res. 71(1): 1-16. https://doi.org/10.2112/si71-001.1

Silva-Casarín R, Mendoza-Baldwin E, Escalante-Mancera E, Mariño-Tapia I, Ruiz-Rentería F. 2009. Oleaje inducido por el huracán Wilma en Puerto Morelos, Quintana Roo, México. Ing. Hidrául. Méx. 24(2): 93-109.

Walsh EJ, Wrigth CW, Vandemark D, Krabill WB, Garcia AW, Houston SH, Murillo ST, Powell MD, Black PG, Marks FD Jr. 2002. Hurricane directional wave spectrum spatial variation at landfall. J. Phys. Oceanogr. 32(6): 1667-1684. https://doi.org/10.1175/1520-0485(2002)032<1667:hdwssv>2.0.co;2

Wang DW, Hwang PA. 2001. An operational method for separating wind sea and swell from ocean wave spectra. J. Atmos. Oceanic Technol.18(12): 2052-2062. https://doi.org/10.1175/1520-0426(2001)018<2052:aomfsw>2.0.co;2

Weinkle J, Maue R, Pielke R Jr. 2012. Historical Global Tropical Cyclone Landfalls. J. Clim. 25(13): 4729-4735. https://doi.org/10.1175/jcli-d-11-00719.1

Young IR. 1998. Observations of the spectra of hurricane generated waves. Ocean Eng. 25(4-5): 261-276. https://doi.org/10.1016/s0029-8018(97)00011-5

Young IR. 2006. Directional spectra of hurricane wind waves. J. Geophys. Res.111: C08020. https://doi.org/10.1029/2006jc003540

Received January 2017, accepted September 2017. 